\title{
ANALISIS MAKNA LEKSIKAL HARF JAR DALAM AL-QUR'AN SURAT AL-FURQAN
}

\author{
Candra Gunawan, Pujiati, Nurlela
}

Program Studi Linguistik (S2) Program Pasca Sarjana

Fakultas Ilmu Budaya,Universitas Sumatera Utara

\begin{abstract}
Abstrak: Tulisan ini bertujuan untuk mengetahui makna leksikal harf jar yang terkandung dalam Al-Qur'an khususnya surat Al-Furqan. Dipilihnya surat AlFurqan karena didalamnya terdapat banyak harf jar dan peneliti berharap setelah ditemukannya makna leksikal harf jar yang terdapat dalam surat tersebut dapat membantu pembaca Al-Qur'an untuk memahami makna yang terkandung di dalamnya. Tulisan ini adalah tulisan kepustakaan (library research) dengan menggunakan metode analisis deskriptif yaitu dengan cara mengumpulkan data, menyusun, dan mengklasifikasi, menganalisis dan menginterpretasinya. Teori yang digunakan adalah teori semantik leksikal dengan merujuk pendapat para ahli linguistik yang dikemukakan oleh Verhaar (1996), Chaer (2012), Pateda (2015), Mukhtar (1998), Khuli (1982). Hasil dari tulisan ini menunjukkan bahwa di dalam surat Al-Furqan terdapat 59 makna leksikal, yang terdiri dari 8 jenis makna dari 8 jenis harf jar. Rinciannya adalah harf jar (preposisi) min makna leksikalnya adalah 'dari', yaitu menyatakan permulaan (al-ibtidā) berjumlah 5. Harf jar (preposisi) ilā makna leksikalnya adalah 'ke, kepada', yaitu menyatakan arah dan tujuan (intihā al-gāyati) berjumlah 9. Harf jar (preposisi) 'an makna leksikalnya adalah 'dari, jauh dari' yaitu melalui, melewati (al-mujāwazah) berjumlah 3. Harf jar (preposisi) alā makna leksikalnya adalah 'di atas' yaitu menyatakan tempat yang tinggi (isti'lā) berjumlah 6 . Harf jar (preposisi) $f \grave{\imath}$ makna leksikalnya adalah 'di, dalam, di dalam' yaitu menandai keterangan tempat, waktu (zarfiyyah) berjumlah 12. Harf jar (preposisi) ba makna leksikalnya adalah 'dengan' yaitu menyatakan alat (isti'ānah) berjumlah 2. Harf jar (preposisi) kaf makna leksikalnya adalah 'seperti, laksana' yaitu bermakna perumpamaan (at-tasybīh) berjumlah 1. Harf jar lam makna leksikalnya adalah 'milik, bagi' menyatakan kepemilikan (al-milk, syibhu al-milk, istiḥqāq dan ikhtișaș) berjumlah 21.
\end{abstract}

Kata Kunci: Surat Al-Furqan, Harf jar, Semantik Leksikal

\section{Pendahuluan}

Bahasa Arab adalah bahasa yang masyhur dengan keistimewaan dan keunikannya. Di antaranya, bahasa Arab merupakan bahasa yang kaya dengan kosa kata, dan termasuk di antaranya dari aspek semantik atau makna kata yang mendalam. Kata, dalam bahasa Arab disebut dengan al-kalimah. Kata dalam bahasa Arab dibagi kepada tiga jenis; isim (nomina), fi'il (verba) dan harf 
(partikel), (Al-Gulāyaini: 1994). Ketiga jenis kata tersebut, memiliki padanan atau persamaan di dalam bahasa Indonesia; kata isim padanannya adalah nomina yang meliputi kata benda, nama orang dan kata sifat, kata fi'il padanannya adalah verba, dan kata harf padanannya adalah partikel.

Al-Gulāyaini (1994) menyebutkan harf adalah kata yang menunjukkan pengertian pada yang lainnya dan tidak ada baginya tanda-tanda yang istimewa sebagaimana yang ada pada isim dan fi'il'. Ali Al-Jarim dan Musthafa Amin (2003) menyebutkan defenisi harf adalah kata yang maknanya tidak sempurna kecuali setelah bersambung dengan kata yang lain. Dari dua defenisi di atas, dapat disimpulkan bahwa harf adalah kata yang menunjukkan pengertian yang belum jelas, kecuali setelah dirangkaikan dengan kata lain dalam kalimat sempurna.

Bahasa Arab memiliki banyak harf. Di antara jenis harf dalam bahasa Arab adalah harf jar. Harf jar berfungsi membuat baris kata berikutnya (nomina) menjadi majrūr (genetif), dan keberadaannya dalam kalimat berperan sangat penting dalam menentukan makna kalimat tersebut. Harf jar dalam Bahasa Indonesia dikenal dengan preposisi. Preposisi adalah kata-kata yang digunakan untuk merangkaikan nomina dengan verba di dalam suatu klausa, (Chaer: 2012). Preposisi jika ditinjau dari perilaku semantisnya, menandai berbagai hubungan makna antara konstituen di depan preposisi tersebut dengan konstituen di belakangnya, (Alwi, dkk: 2003).

Setiap harf jar memiliki makna tersendiri, tetapi harf jar dimaksud tidak saja memiliki satu makna, justru mengandung makna-makna lain ketika harf jar itu telah masuk dalam struktur kalimat bahasa Arab. Seperti harf jar من /min/, makna aslinya adalah al-ibtid $\bar{a}$ ' yaitu menerangkan tentang permulaan, baik permulaan tempat atau waktu (Al-Gulāyayni, 1994). Tetapi dalam konteks yang berbeda bisa dimaknai dengan selainnya. Demikian halnya dengan jenis harf-harf jar lainnya. Contohnya dapat kita lihat di dalam surat Al-Furqān berikut ini:

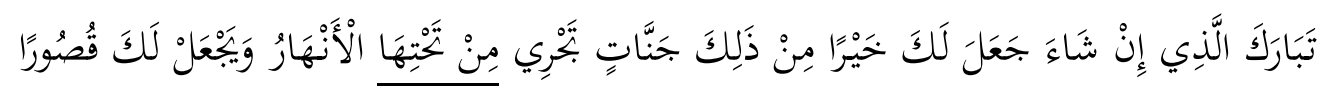

Itabāraka al-laźì in syāa ja'ala laka khairan min źálika jannātin tajrī min taḥtihā al-anhāru wa yaj'al laka quşūral 'Maha Suci (Allah) yang jika 
Dia menghendaki, niscaya Dia jadikan bagimu yang lebih baik daripada itu, (yaitu) surga-surga yang mengalir dari bawahnya sungai-sungai, dan Dia jadikan (pula) istana-istana untukmu'. (Q.S. Al-Furqan: 10)

Harf jar من / $/ \mathrm{min} /$ pada ayat di atas berkaitan dengan kata sebelumnya, yakni kata kerja تجري /tajrīl, artinya mengalir (Darwisy: 2011). Ayat di atas menerangkan tentang surga yang mengalir dari bawahnya air sungai. Makna harf jar ابتداء الغاية إmin/ pada ayat ini adalidā' al-gāyatil yaitu menerangkan permulaan, yaitu air sungai yang mengalir dari bawah surga. Dalam bahasa Indonesia harf jar min diartikan dengan 'dari', (Munawwir: 1997). Para ahli bahasa Arab mengatakan bahwa dari kebanyakan makna harf jar min adalah menerangkan permulaan sesuatu (Al-Anşāri, 1998).

Contoh lainnya,

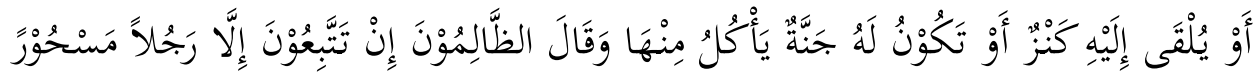
lau yulqā ilahi kanzun au takūnu lahu jannatun ya 'kulu minhā wa qālū azzălimūna in tattabi'ūna illā rajulan masḥ̂̄rāl 'Atau (mengapa tidak) diturunkan kepadanya perbendaharaan, atau dia mempunyai kebun yang ia makan darinya? Dan berkata pula orang-orang yang aniaya itu, bahwasanya yang kamu ikuti itu hanyalah seseorang yang telah dirasuk sihir'. (Q.S: Al-Furqan: 8)

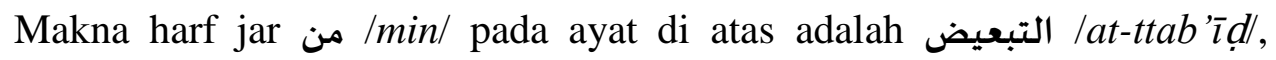
artinya menunjukkan 'sebagian'. Hasan (2004) mengatakan bahwa tanda harf jar min bermakna sebagian adalah jika kata sebelum harf jar min -biasanya- adalah bagian dari kata yang di jarkan (genetifkan) olehnya. Maka harf jar min pada ayat هـ di atas yang bersambung dengan kata ganti bersambung (dhamīr muttaşil) yaitu yaitu منها /minhā/ merujuk kepada kata جنة /jannah/ 'kebun', yang merupakan acuannya. Sehingga makna harf jar min di atas adalah التبعيض /at-tab’ọd/ 'sebagian', yang artinya adalah Atau (mengapa tidak) diturunkan kepadanya 
perbendaharaan, atau dia mempunyai kebun yang ia makan sebagiannya (buahbuahannya)?. Makna $b a$ 'd dalam bahasa Indonesia diartikan 'sebagian' (Munawwir, 1997).

Beragamnya makna harf-harf jar dimaksud menjadi problema tersendiri bagi pelajar bahasa Arab non Arab, khususnya bagi pemula. Pelajar bahasa Arab harus lebih teliti dan berhati-hati dalam menggunakan harf jar tersebut sehingga dinilai tepat dalam pemakaian dan penerjemahannya, apalagi untuk memahami makna-makna harf jar yang terdapat dalam setiap kata di dalam Al-Qur'an. Hal inilah yang membuat peneliti tertarik untuk melakukan tulisan terhadap maknamakna harf jar yang terkandung dalam dalam Al-Qur'an. Pada tulisan ini peneliti ingin meneliti makna leksikal dari harf-harf jar yang terdapat dari salah satu surat di dalam Al-Qur'an yaitu surat Al-Furqān. Alasan peneliti memilih surat Al-Furqān sebagai objek tulisan dikarenakan belum adanya tulisan sebelumnya terhadap harf jar yang terdapat di dalam surat Al-Furqān serta didalam surat AlFurqān terdapat lebih dari 100 harf jar, sehingga sangat menarik untuk dijadikan subjek tulisan, karena banyak makna yang muncul dari harf jar tersebut.

Pada tulisan ini peneliti memfokuskan kajian tentang makna leksikal dari harf jar yang terdapat dalam Al-Qur'an surat Al-Furqān. Teori yang digunakan untuk menjawab masalah tulisan ini yaitu teori semantik leksikal dengan merujuk pendapat para ahli linguistik yang dikemukakan oleh Verhaar (1996), Chaer (2012), Pateda (2015), Mukhtar (1998), Khuli (1982) serta para ahli linguistik lainnya, yang menyebutkan bahwa makna leksikal adalah makna dasar dari kata itu sendiri atau juga disebut dengan makna yang terdapat dalam mu'jam (kamus).

Tulisan ini adalah penelitian kepustakaan (library research) dengan menggunakan metode analisis deskriptif yaitu dengan cara mengumpulkan data, menyusun, dan mengklasifikasi, menganalisis dan menginterpretasinya, (Surakhmad, 1989). Nazir (2003) menyebutkan, Studi kepustakaan adalah teknik pengumpulan data dengan mengadakan studi penelaahan terhadap buku-buku, literatur-literatur, catatan-catatan, dan laporan-laporan yang ada hubungannya dengan masalah yang dipecahkan.” 
Sumber data dalam tulisan ini adalah ayat-ayat Al-Qur'an dari surat AlFurqān milik Departemen Agama Republik Indonesia. Data dalam peneliti ini adalah semua jenis harf jar yang terdapat dalam surat Al-Furqān.

Analisis data yang pada tulisan ini adalah dengan menggunakan beberapa langkah sesuai teori Miles, Huberman dan Saldana (2014) yaitu menganalisis data dengan tiga langkah: kondensasi data (data condensation), menyajikan data (data display), dan menarik simpulan atau verifikasi (conclusion drawing and verification).

\section{PEMBAHASAN}

Makna leksikal adalah makna kata ketika kata itu berdiri sendiri, entah dalam bentuk leksem atau bentuk berimbuhan yang maknanya kurang lebih tetap, seperti yang dapat dibaca di dalam kamus bahasa tertentu. Peneliti menemukan makna leksikal harf jar yang terdapat dalam surat Al-Furqān berjumlah 59 makna yang terdiri dari 8 jenis makna dari 8 harf jar. Berikut makna leksikal harf jar di dalam Al-Qur'an surat Al-Furqan:

\section{Harf jar من /min/}

Makna leksikal dari harf jar من /min/ adalah dari (Munawwir: 1997) Dalam bahasa indonesia kata 'dari' merupakan preposisi yang menunjukkan tempat permulaan (Depdikbud: 1995). Dalam surat Al-Furqan terdapat 5 makna leksikal harf jar min yang berada pada ayat ke-10, ayat ke-12, ayat ke-48, ayat ke54 dan ayat ke-74.

\begin{tabular}{|c|c|c|}
\hline $\begin{array}{l}\text { l...tajrī min tahtihā al-anhāru.../'...mengalir } \\
\text { dari bawahnya sungai-sungai...’.(QS. Al- } \\
\text { Furqān: } 10)\end{array}$ & 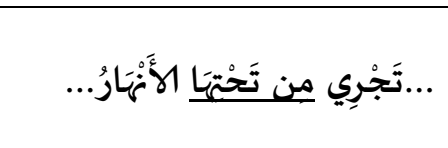 & 1 \\
\hline 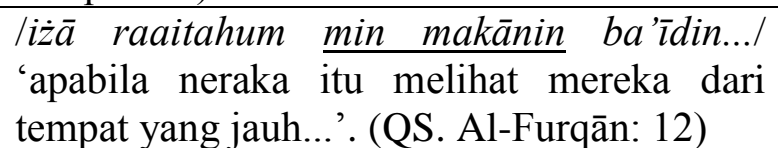 & تُهُمَم مِّنَ مَّكَانِ & 2 \\
\hline $\begin{array}{l}\text { l...wanzalnā minas samāi māan țahūral } \\
\text { '...dan Kami turunkan dari langit air yang } \\
\text { amat bersih'. (Q S. Al-Furqān: 48) }\end{array}$ & طَعَُورًا & 3 \\
\hline
\end{tabular}




\begin{tabular}{|c|c|c|}
\hline $\begin{array}{l}\text { /wahuwa al-laż̀ khalaqa mina al-mīi } \\
\text { basyaran.../ 'dan Dia pula yang menciptakan } \\
\text { manusia dari air...'. (QS. Al-Furqān: 54) }\end{array}$ & 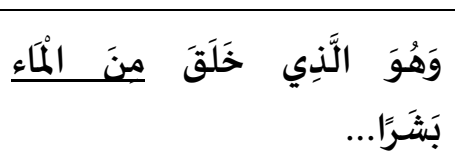 & 4 \\
\hline 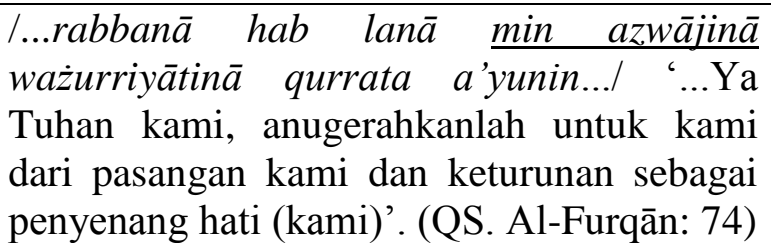 & 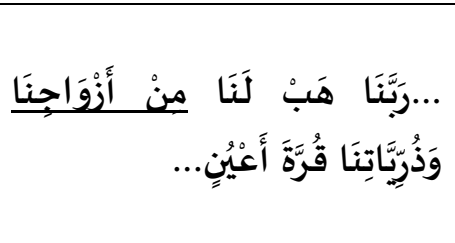 & 5 \\
\hline
\end{tabular}

Makna harf jar من /min/ pada ayat-ayat di atas adalah الابتداء /al-ibtidā/, من maitu menyatakan permulaan, maksudnya kata yang dimasuki oleh harf jar /min/ merupakan permulaan pada makna kalimat yang berhubungan. Peneliti menyimpulkan makna al-ibtidā dari harf jar min sebagai makna leksikal karena makna al-ibtidā berpadanan dengan makna kata 'dari' dalam bahasa Indonesia, yaitu sama-sama menyatakan tempat permulaan (Depdikbud, 1995). Para ahli bahasa Arab mengatakan bahwa kebanyakan makna harf jar min adalah menerangkan permulaan (Al-Anşāri, 1998).

\section{Harf jar إliläl}

Makna leksikal dari harf jar إلى /ilä/ adalah ke, kepada (Munawwir: 1997) Dalam bahasa indonesia kata 'ke, kepada' merupakan preposisi yang menandai arah dan tujuan (Depdikbud: 1995). Dalam surat Al-Furqan terdapat 9 makna leksikal harf jar ilā yang berada pada ayat ke-7, ayat ke-8, ayat ke-23, ayat ke-34, ayat ke-36, ayat ke-45, ayat ke-46, ayat ke-57 dan ayat ke-71.

\begin{tabular}{|c|c|c|}
\hline $\begin{array}{l}\text { l...lau lā unzila ilaihi malakun fayakūnu } \\
\text { ma'ahu nażīral '...Mengapa tidak } \\
\text { diturunkan kepadanya malaikat, untuk } \\
\text { memberikan peringatan bersama-sama } \\
\text { dengan dia'. (QS. Al-Furqān: 7) }\end{array}$ & مَعَهُ نَذِيْراً & 1 \\
\hline $\begin{array}{l}\text { lau yulqā ilaihi kanzun.../ 'atau mengapa } \\
\text { tidak diturunkan kepadanya harta } \\
\text { kekayaan...'. (QS. Al-Furqān: 8) }\end{array}$ & 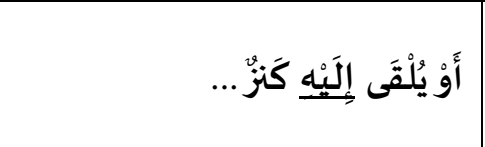 & 2 \\
\hline $\begin{array}{l}\text { Iwaqadimnā ilā mā 'amilū min 'amalin.../ } \\
\text { 'Dan Kami akan perlihatkan kepada mereka } \\
\text { segala amal yang mereka kerjakan...'. (QS. } \\
\text { Al-Furqān: 23) }\end{array}$ & مَلٍٍ... & 3 \\
\hline
\end{tabular}




\begin{tabular}{|c|c|c|}
\hline $\begin{array}{l}\text { lallażina yuhsyarūna 'alā wujūhihim } \underline{\text { ilāa }} \\
\text { jahannama.../ 'Orang-orang yang } \\
\text { dikumpulkan ke neraka Jahannam dengan } \\
\text { diseret di atas wajah-wajah mereka...'. (QS. } \\
\text { Al-Furqān: } 34 \text { ) }\end{array}$ & 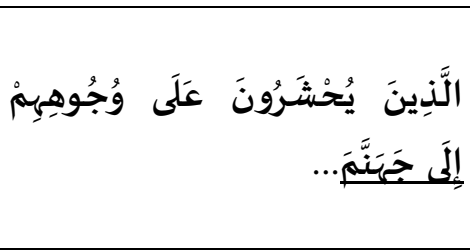 & 4 \\
\hline 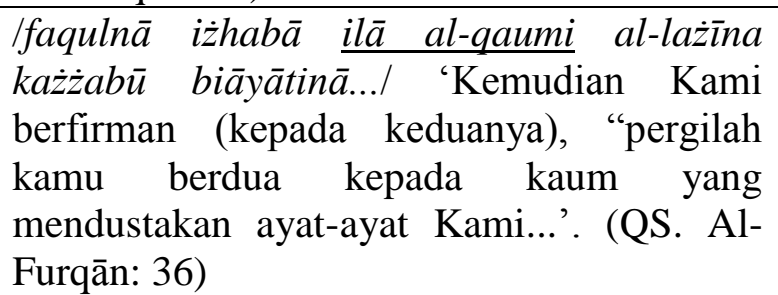 & 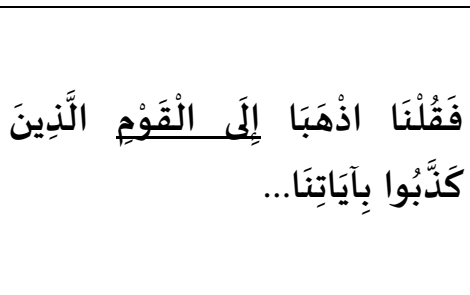 & 5 \\
\hline $\begin{array}{l}\text { lalam tara ilā rabbika kaifa maddaź źilla.../ } \\
\text { 'Tidakkah engkau memperhatikan kepada } \\
\text { (penciptaan) Tuhanmu, bagaimana Dia } \\
\text { memanjangkan (dan memendekkan) } \\
\text { bayang-bayang...'. (QS. Al-Furqān: 45) }\end{array}$ & 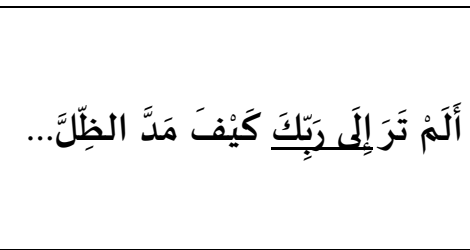 & 6 \\
\hline $\begin{array}{l}\text { Iśumma qabaḍāhu ilainā qabḍan yasīral } \\
\text { 'Kemudian Kami menarik bayang-bayang } \\
\text { itu kepada Kami sedikit demi sedikit'. (QS. } \\
\text { Al-Furqān: 46) }\end{array}$ & ثُمَّ قَبَضْنَنَاهُ إِلَيْنَا قَبْضًِا يَسِيرًا & 7 \\
\hline $\begin{array}{l}\text { /...illāa man syāa an yattakhiżu ilāa rabbihi } \\
\text { sabülal '....melainkan mengharapkan orang- } \\
\text { orang mau mengambil jalan kepada } \\
\text { Tuhannya'. (QS. Al-Furqān: } 57)\end{array}$ & 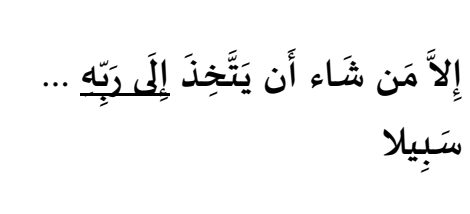 & 8 \\
\hline $\begin{array}{l}\text { Iwaman tāba wa 'amila şālihan fainnahū } \\
\text { yatūbu ila allāhi matābal 'Dan barangsiapa } \\
\text { bertaubat dan mengerjakan kebajikan, maka } \\
\text { sesungguhnya dia bertaubat kepada Allah } \\
\text { dengan taubat yang sebenar-benarnya'. (QS. } \\
\text { Al-Furqān: 71) }\end{array}$ & 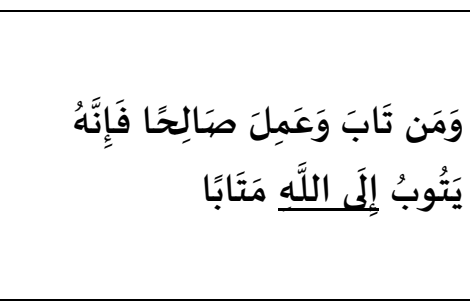 & 9 \\
\hline
\end{tabular}

Makna harf jar إلى إنهاء الغاية /ilintih/ pada ayat-ayat di atāayatil, yaitu menerangkan akhir dari sesuatu, tujuan. Peneliti menyimpulkan makna intihà al-gāyati dari harf jar ilā sebagai makna leksikal karena makna intihā algāyati berpadanan dengan makna kata 'ke, kepada' dalam bahasa Indonesia, yaitu sama-sama menandai arah atau tujuan (Depdikbud, 1995).

\section{Harf jar عن /'an/}

Makna leksikal dari harf jar عن /'an/ adalah daripada, dari, jauh dari (Yunus: 1989) Dalam bahasa Indonesia kata 'daripada' merupakan preposisi untuk menandai perbandingan dan kata 'dari' juga merupakan preposisi yang 
salah satu maknanya adalah melalui, melewati (Depdikbud: 1995). Dalam surat Al-Furqan terdapat 3 makna leksikal harf jar'an yang berada pada ayat ke-29, ayat ke-42, dan ayat ke-65.

\begin{tabular}{|c|c|}
\hline $\begin{array}{l}\text { llaqad a dallanī 'an żikri.../ 'sesungguhnya dia } \\
\text { telah menyesatkan aku dari Al-Qur'an'. (QS. } \\
\text { Al-Furqān: 29) }\end{array}$ & لَقَدْ أَضَضَلَّنِي عَرَنِ الذَّكُرِِ. \\
\hline $\begin{array}{l}\text { /in kāda layudilliunā 'an àlihatinā.../ } \\
\text { 'sesungguhnya, hampirlah ia menyesatkan } \\
\text { kita dari sesembahan-sesembahan kita...'. } \\
\text { (QS. Al-Furqān: 42) }\end{array}$ & 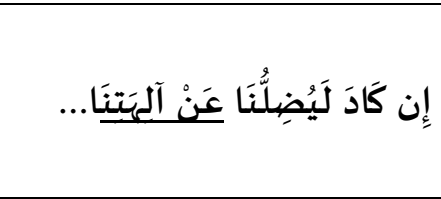 \\
\hline $\begin{array}{l}\text { Iwa al-lażīna yaqūlūna rabbanā işrif ‘annā } \\
\text { 'ażāba jahannama.../ 'Dan orang-orang yang } \\
\text { berkata, "Ya Tuhan kami, jauhkanlah azab } \\
\text { jahannam dari kami...'. (QS. Al-Furqān: 65) }\end{array}$ & 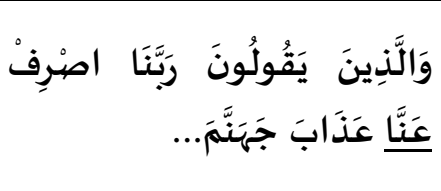 \\
\hline
\end{tabular}

Makna harf jar عن /'an/ pada ayat-ayat di atas المجاوزة /al-mujāwazatul, yang artinya melalui, melewati. Makna al-mujāwazatu berpadanan dengan salah satu makna kata 'dari' dalam bahasa Indonesia, yaitu melalui, melewati (Depdikbud, 1995).

\section{Harf jar على /'alä|}

Makna leksikal dari harf jar على /'aläl adalah di atas (Munawwir: 1997) Dalam bahasa Indonesia kata 'atas' menyatakan tempat yang tinggi (Depdikbud, 1995). Dalam surat Al-Furqan terdapat 6 makna leksikal harf jar 'alā yang berada pada ayat ke-34, ayat ke-42, ayat ke-43, ayat ke-45, ayat ke-59 dan ayat ke-63.

\begin{tabular}{|c|c|}
\hline $\begin{array}{l}\text { lallażina yuhsyarūna 'alā wujūhihim ilā } \\
\text { jahannama.../ 'orang-orang yang } \\
\text { dikumpulkan ke neraka Jahannam dengan } \\
\text { diseret di atas wajah-wajah mereka...'. (QS. } \\
\text { Al-Furqān: } 34 \text { ) }\end{array}$ & 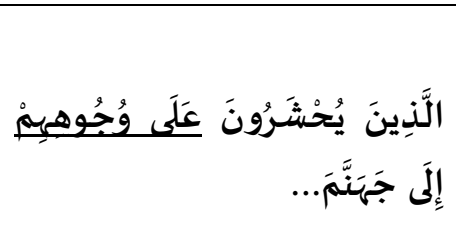 \\
\hline $\begin{array}{l}\text { lin kāda layu dillunā 'an àlihatinā laulā an } \\
\text { şabarnā 'alaihā.../ 'sesungguhnya, } \\
\text { hampirlah ia menyesatkan kita dari } \\
\text { sesembahan-sesembahan kita, seandainya } \\
\text { kita tidak sabar diatasnya (menyembah) } \\
\text { nya... (QS. Al-Furqān: 42) }\end{array}$ & 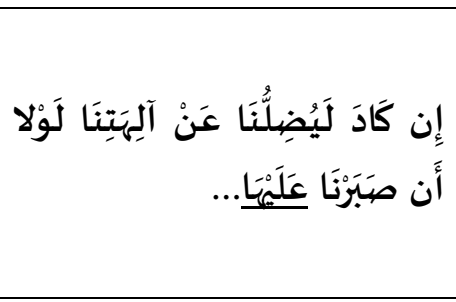 \\
\hline laraaita man ittakhaża ilāhahu hawāhu & 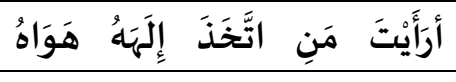 \\
\hline
\end{tabular}




\begin{tabular}{|c|c|c|}
\hline $\begin{array}{l}\text { afaanta takūnu 'alaihi wakīläl } \\
\text { 'Terangkanlah kepadaku tentang orang yang } \\
\text { menjadikan hawa nafsunya sebagai } \\
\text { tuhannya. Maka apakah kamu dapat menjadi } \\
\text { pemelihara atasnya?'. (QS. Al-Furqān: } 43 \text { ) }\end{array}$ & أَفَأَنَتَ تَكُونُ عَلَبِيْهِ وَكِيلا & \\
\hline $\begin{array}{l}\text { l...walau syāa laja'alahu sākinan śumma } \\
\text { ja'alnā as-syamsa 'alaihi dalīlal '...dan } \\
\text { kalau Dia menghendaki, niscaya Dia } \\
\text { menjadikan bayang-bayang itu tetap, } \\
\text { kemudian Kami jadikan matahari sebagai } \\
\text { petunjuk atas bayang-bayang itu'. (QS. Al- } \\
\text { Furqān: 45) }\end{array}$ & 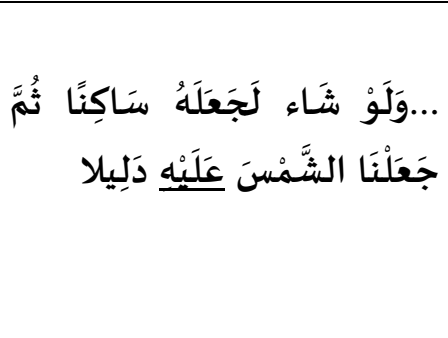 & 4 \\
\hline $\begin{array}{l}\text { l...śumma istawā 'alā al'arsyi ar- } \\
\text { rahmmānu.../ '...kemudian Dia bersemayam di } \\
\text { atas Arasy, (Dialah) yang Maha Pengasih...' } \\
\text { (QS. Al-Furqān: 59) }\end{array}$ & 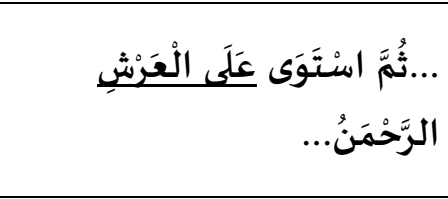 & 5 \\
\hline $\begin{array}{l}\text { lwa 'ibädu ar-rahmmāni al-lażina yamsyūna } \\
\text { 'ala al-ardi haunan.../ 'Adapun hamba- } \\
\text { hamba Tuhan yang Maha Pengasih itu } \\
\text { adalah orang-orang yang berjalan di atas } \\
\text { bumi dengan rendah hati...'. (QS. Al- } \\
\text { Furqān: } 63 \text { ) }\end{array}$ & 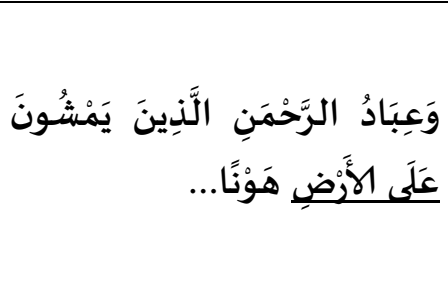 & 6 \\
\hline
\end{tabular}

Makna harf jar استعلاء /'alāl pada ayat-ayat di atasti'lāl, yang artinya menyatakan tinggi, di atas. Peneliti menyimpulkan makna isti'lā sebagai makna leksikal karena makna tersebut berpadanan dengan makna kata 'atas' dalam bahasa Indonesia, yaitu menyatakan tempat yang tinggi (Depdikbud, 1995).

\section{Harf jar فfiآ|}

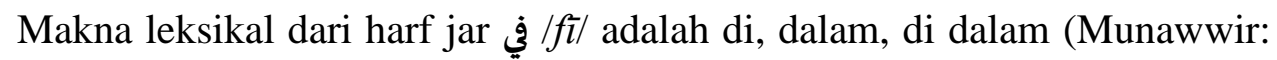
1997). Dalam bahasa Indonesia kata di dan dalam merupakan preposisi untuk menerangkan tempat, waktu (Depdikbud, 1995). Dalam surat Al-Furqan terdapat 12 makna leksikal harf jar $f i$ yang berada pada ayat ke-2, ayat ke-6, ayat ke-7, ayat ke-16, ayat ke-20, ayat ke-21, ayat ke-59, ayat ke-61, ayat ke-69, ayat ke-75 dan ayat ke-76.

I...walam yakun lahū syarīkun fi al-mulki wa khalaqa kulla syain faqaddarahu taqdìral '...tidak ada sekutu bagi-Nya dalam kekuasaan (Nya), dan Dia menciptakan segala sesuatu, lalu menetapkan ukuranukurannya dengan tepat'. (QS. Al-Furqān:2)

مَأَلَ... وَخَلَقَ كُلَّ شَيْيٍْ فَقَدَّرَهُ تَقْدِيرًا 


\begin{tabular}{|c|c|c|}
\hline $\begin{array}{l}\text { lqul anzalahu al-laż̄ ya'lamu as-sirra fì as- } \\
\text { samāwāti wa al-ardi.../ 'Katakanlah } \\
\text { Muhammad, Al-Qur'an itu diturunkan oleh } \\
\text { Allah yang mengetahui rahasia di langit dan } \\
\text { di bumi.... (Q. S. Al-Furqān: 6) }\end{array}$ & 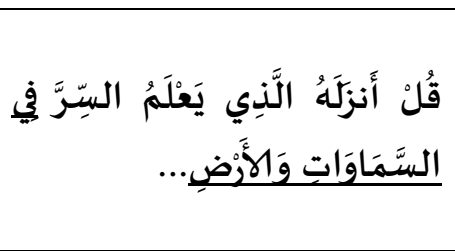 & 2 \\
\hline 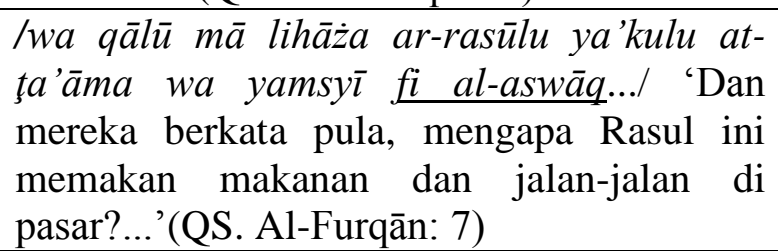 & 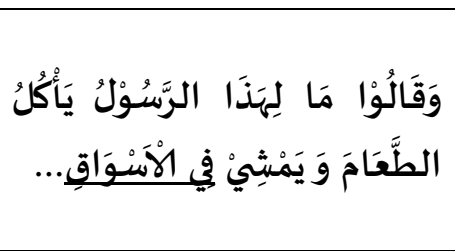 & 3 \\
\hline $\begin{array}{l}\text { /lahum fìhā mā yasyā'ūna khālidīna.../ 'Bagi } \\
\text { mereka segala yang mereka kehendaki ada } \\
\text { di dalamnya (surga), mereka kekal (di } \\
\text { dalamnya)... (QS. Al-Furqān: 16) }\end{array}$ & لَهُمْ فيهيَا مَا يَشَاؤُونَ خَالِلِدينَ... & 4 \\
\hline $\begin{array}{l}\text { /wamā arsalnā qablaka mina al-mursalīna } \\
\text { illāa innahum laya'kulūna at-ța'āma } \\
\text { wayamsyūna fi al-aswāq.../ 'Dan Kami tidak } \\
\text { mengutus rasul-rasul sebelummu } \\
\text { (Muhammad), melainkan mereka pasti } \\
\text { memakan makanan dan berjalan di pasar- } \\
\text { pasar...'. (QS. Al-Furqān: 20) }\end{array}$ & 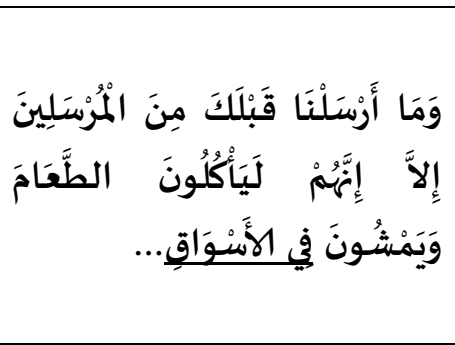 & 5 \\
\hline $\begin{array}{l}\text { l...laqad istakbarū fí anfusihim wa'atau } \\
\text { 'utuwwan kabīral'...Sungguh, mereka telah } \\
\text { menyombongkan diri mereka dan benar- } \\
\text { benar telah melampaui batas (dalam } \\
\text { melakukan kezaliman'. (QS. Al-Furqān: } 21 \text { ) }\end{array}$ & 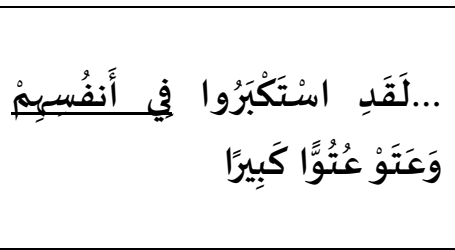 & 6 \\
\hline $\begin{array}{l}\text { lallaż̄ khalaqa as-samāwāti wa al-arḍa } \\
\text { wamā bainahumā fì sittati ayyāmin..../'Yang } \\
\text { menciptakan langit dan bumi dan apa yang } \\
\text { ada di antara keduanya dalam enam masa...'. } \\
\text { (QS. Al-Furqān: 59) }\end{array}$ & 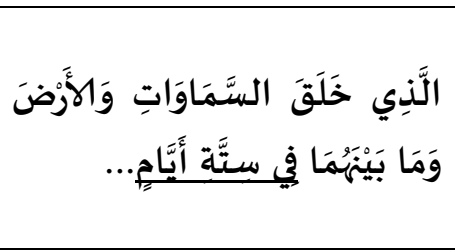 & 7 \\
\hline $\begin{array}{l}\text { Itabāraka al-laż̀̄ ja'ala fi as-samāi burūjan } \\
\text { waja'ala fĭha sirājan waqamaran munīral } \\
\text { 'Maha suci Allah yang menjadikan di langit } \\
\text { gugusan bintang-bintang dan Dia juga } \\
\text { menjadikan padanya matahari dan bulan } \\
\text { yang bersinar'. (QS. Al-Furqān: 61) }\end{array}$ & 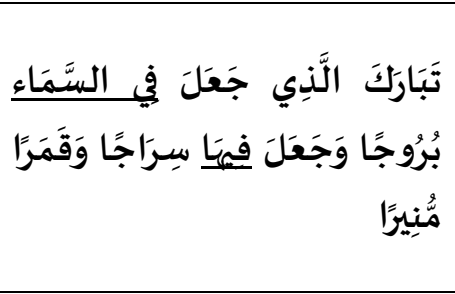 & 8 \\
\hline $\begin{array}{l}\text { lyuḍāaf lahu al-'ażābu yauma al-qiyāmati } \\
\text { waykhlud fìhi muhānal 'Akan } \\
\text { dilipatgandakan azab untuknya pada hari } \\
\text { kiamat dan dia akan kekal dalam azab itu, } \\
\text { dalam keadaan terhina'. (QS. Al-Furqān: 69) }\end{array}$ & 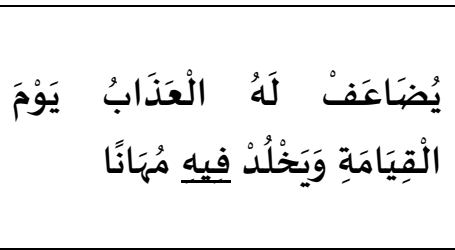 & 9 \\
\hline $\begin{array}{l}\text { I...wa yulaqqauna fihā tahiyyatan wa } \\
\text { salāmal '...dan di surga mereka akan } \\
\text { disambut dengan penghormatan dan salam'. } \\
\text { (QS. Al-Furqān: 75) }\end{array}$ & وَْنَ فِيَِا تَحِيَّةً وَسَلامًا & 10 \\
\hline $\begin{array}{l}\text { Ikhālidīna fīhā hasunat mustaqarran wa } \\
\text { muqāmal 'Mereka kekal di dalamnya. Surga }\end{array}$ & خَالِلِدِينَ فيهًَا حَسُنَتْ مُسنْنَقَرًا & 11 \\
\hline
\end{tabular}


itu sebaik-baik tempat menetap dan tempat kediaman'. (QS. Al-Furqān: 76)

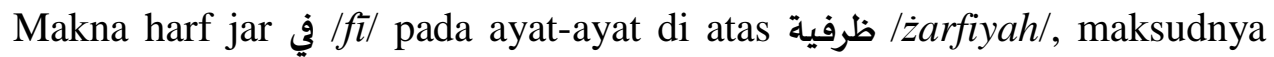
adalah kata yang dimasuki oleh harf jar fi merupakan keterangan, baik keterangan tempat ataupun waktu dari makna kalimat yang berhubungan dan. Peneliti menyimpulkan makna żarfiyah sebagai makna leksikal karena makna tersebut berpadanan dengan makna kata 'di, dalam' dalam bahasa Indonesia, yaitu menandai tempat, waktu (Depdikbud, 1995).

\section{Harf jar ب/ba/}

Makna leksikal dari harf jar ب/ba/ adalah dengan, demi (Yunus: 1989). Dalam bahasa Indonesia kata 'dengan' menyatakan alat dan kata 'demi' untuk menyatakan sumpah (Depdikbud, 1995). Dalam surat Al-Furqan terdapat 2 makna leksikal harf jar $b a$ yang berada pada ayat ke-32 dan ayat ke-52.

\begin{tabular}{|c|c|c|}
\hline $\begin{array}{l}\text { /...każālika linuśabbitu bihi fuãdaka.../ } \\
\text { '...Demikianlah, agar Kami memperteguh } \\
\text { hatimu (Muhammad) dengannya (Al- } \\
\text { Qur'an)...'(QS. Al-Furqān: 32) }\end{array}$ & ...كَذَلِكَكَ لِنْثَتِبَتَ بِهِ فُؤَادَكَكَ... & 1 \\
\hline $\begin{array}{l}\text { Ifalā tuţi'il kāfirīna wajāhidhum bihī } \\
\text { jihādan kabìral 'Maka janganlah engkau } \\
\text { taati orang-orang kafir, dan berjuanglah } \\
\text { terhadap mereka dengan Al-Qur'an dengan } \\
\text { perjuangan yang besar'. (QS. Al-Furqān: 52) }\end{array}$ & 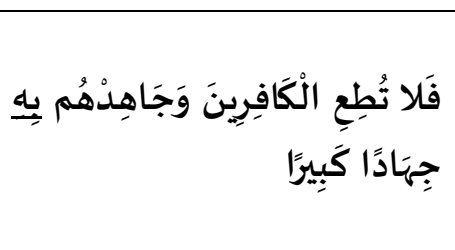 & 2 \\
\hline
\end{tabular}

Makna harf jar ب/ba/ pada ayat-ayat di atas adalah الاستعانة /al-isti'ānah/. Maksudnya harf jar yang masuk kepada alat dari sebuah kata kerja, yang mana kata yang dimasuki oleh harf jar ba merupakan alat yang digunakan untuk mewujudkan makna pada kata kerja sebelumnya. Dalam Bahasa Indonesia diartikan 'dengan'.

\section{Harf jar ك /kafl}

Makna leksikal dari harf jar ك/kafl adalah seperti, laksana (Munawwir: 1997) Dalam bahasa Indonesia kata 'seperti dan laksana' bermakna perumpamaan. Dalam surat Al-Furqan terdapat 1 makna leksikal harf jar kaf yang 
التشبيه الك ا ك bafl bermakna pada ayat ke-44 dan pada ayat tersebut harf jar lat-tasybīh/ yaitu menyatakan perumpamaan.

\begin{tabular}{|c|c|}
\hline $\begin{array}{l}\text { lam tah̆sabu anna akśarahum yasma'ūna au } \\
\text { ya'qilüna in hum illā ka al-an'āmi bal hum } \\
\text { aḍallu sabīlāl 'Atau apakah engkau mengira } \\
\text { bahwa kebanyakan mereka itu mendengar } \\
\text { atau memahami? Mereka itu hanyalah } \\
\text { seperti hewan ternak, bahkan lebih sesat } \\
\text { jalannya'. (QS. Al-Furqān: 44) }\end{array}$ & 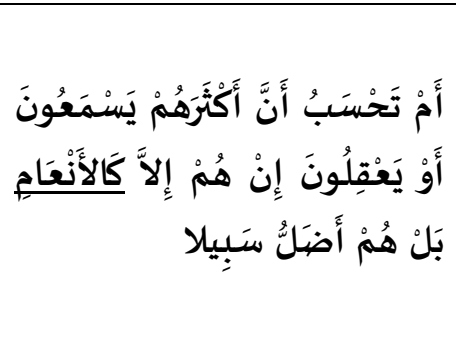 \\
\hline
\end{tabular}

\section{Harf jar J/lam/}

Makna leksikal dari harf jar J/lam/ adalah milik, bagi (Munawwir: 1970.

Dalam surat Al-Furqan terdapat 21 makna leksikal harf jar kaf yang berada pada ayat ke-2, ayat ke-26, ayat ke-1, ayat ke-8, ayat ke-10, ayat ke-11, ayat ke-15, ayat ke-22, ayat ke-37, ayat ke-60, ayat ke-69, ayat ke-12, ayat ke-16, ayat ke-18, ayat ke-29, ayat ke-31, ayat ke-37, ayat ke-64 dan ayat ke-74.

\begin{tabular}{|c|c|c|}
\hline $\begin{array}{l}\text { lallaż̀ lahu mulku as-samāwāti wa al-ardị.../ } \\
\text { 'Yang memiliki kerajaan langit dan bumi...' } \\
\text { (QS. Al-Furqān: 2) }\end{array}$ & 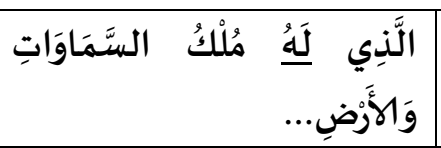 & 1 \\
\hline $\begin{array}{l}\text { lalmulku yaumaiżin alhaqqu lirraḥmāni.../ } \\
\text { 'Kerajaan yang hak pada hari itu milik } \\
\text { Tuhan yang Maha Pengasih...'.(QS. Al- } \\
\text { Furqān: 26) }\end{array}$ & 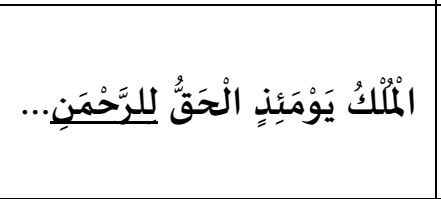 & 2 \\
\hline $\begin{array}{l}\text { l...liyakūna lil 'àlamīna nażīral '...agar dia } \\
\text { menjadi pemberi peringatan bagi } \\
\text { alam (jin dan manusia)'. (QS. Al-Furqān: } 1)\end{array}$ & 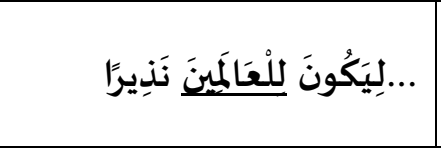 & 3 \\
\hline $\begin{array}{l}\text { law yulqā ilaihi kanzun au takūnu lahu } \\
\text { jannatun ya'kulu minhā.../ 'Atau mengapa } \\
\text { tidak diturunkan kepadanya harta kekayaan } \\
\text { atau mengapa tidak ada kebun baginya, } \\
\text { sehingga dia dapat makan dari (hasil) } \\
\text { nya...?'. (QS. Al-Furqān: } 8 \text { ) }\end{array}$ & 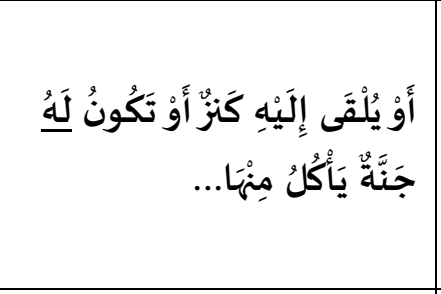 & 4 \\
\hline $\begin{array}{l}\text { I...wa yaj'al laka quşūral'...dan Dia jadikan } \\
\text { (pula) istana-istana untukmu'. (QS. Al- } \\
\text { Furqān: 10) }\end{array}$ & |... وَيَجْعَلَ لََكَ قُصُورًا & 5 \\
\hline $\begin{array}{l}\text { Ibal każżabū bissā'ati wa a'tadnā liman } \\
\text { każżaba biss'âti sā'iral 'Bahkan mereka } \\
\text { mendustakan hari kiamat. Dan kami } \\
\text { menyediakan neraka yang menyala-nyala } \\
\text { bagi siapa yang mendustakan hari Kiamat'. }\end{array}$ & 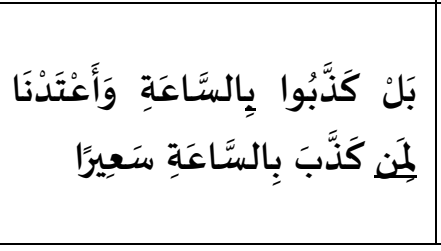 & 6 \\
\hline
\end{tabular}




\begin{tabular}{|c|c|c|}
\hline $\begin{array}{l}\text { lqul ażălika khairun am jannatu al-khuldi } \\
\text { al-latī wu'ida al-muttaqūna kānat lahum } \\
\text { jazā'n wa maşīral 'Katakanlah } \\
\text { (Muhammad), “Apakah (azab) seperti itu } \\
\text { yang baik, atau surga yang kekal yang } \\
\text { dijanjikan kepada orang-orang yang } \\
\text { bertakwa sebagai balasan, dan tempat } \\
\text { kembali mereka?'. (QS. Al-Furqān: 15) }\end{array}$ & 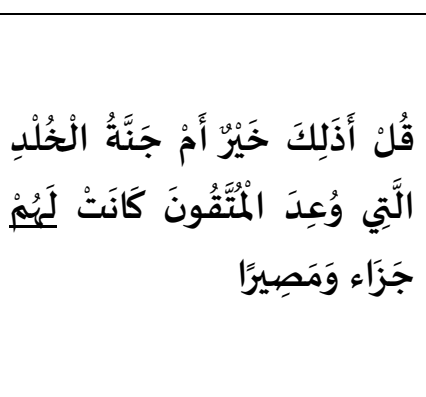 & 7 \\
\hline $\begin{array}{l}\text { lyauma yarauna al-malāikata lā busyrā } \\
\text { yaumaizin li al-mujrimīn.../ 'Ingatlah pada } \\
\text { hari (ketika) mereka melihat para malaikat, } \\
\text { pada hari itu tidak ada kabar gembira bagi } \\
\text { orang-orang yang berdosa.. (QS. Al-Furqān: } \\
\text { 22) }\end{array}$ & 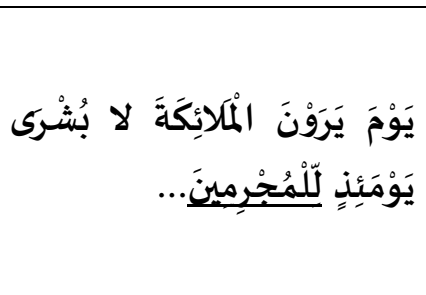 & 8 \\
\hline $\begin{array}{l}\text { l...waa'tadnā liźźālimīna ‘ażāban alimal } \\
\text { '...Dan Kami telah sediakan bagi orang- } \\
\text { orang zalim azab yang pedih'. (QS. Al- } \\
\text { Furqān: } 37 \text { ) }\end{array}$ & 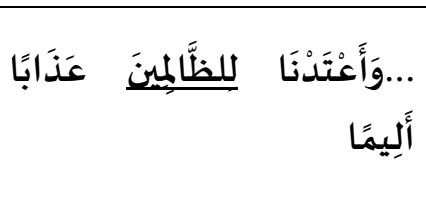 & 9 \\
\hline 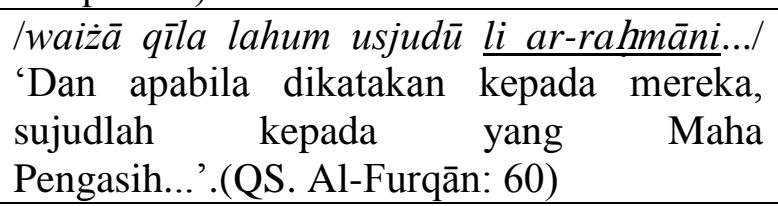 & 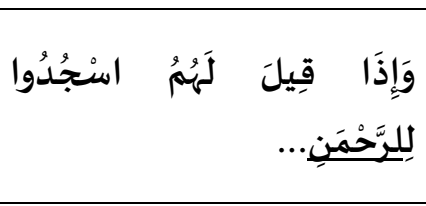 & 10 \\
\hline $\begin{array}{l}\text { lyuḍāaf lahu al-'ażābu yauma al-qiyāmati } \\
\text { waykhlud fìhi muhānal 'Akan } \\
\text { dilipatgandakan azab untuknya pada hari } \\
\text { kiamat dan dia akan kekal dalam azab itu, } \\
\text { dalam keadaan terhina'. (QS. Al-Furqān: 69) }\end{array}$ & 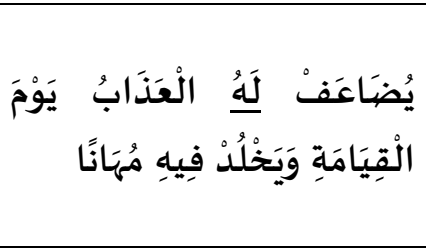 & 11 \\
\hline $\begin{array}{l}\text { l...walam yattakhiż waladan walam yakun } \\
\text { lahu syarīkun fil mulki... ...tidak } \\
\text { mempunyai anak, tidak ada sekutu bagi-Nya } \\
\text { dalam kekuasaan (Nya)...'. (QS. Al-Furqān: } \\
\text { 2) }\end{array}$ & 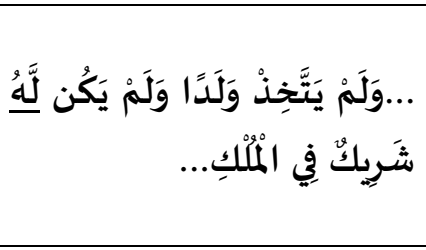 & 12 \\
\hline 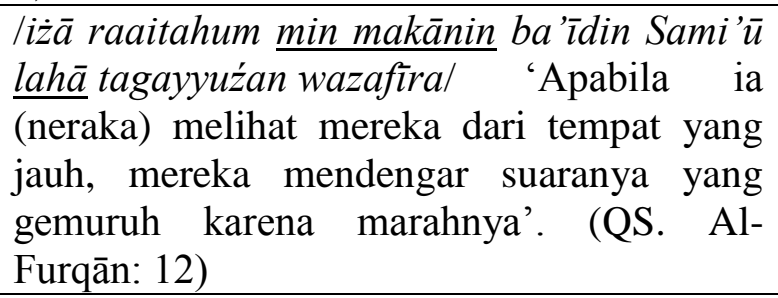 & 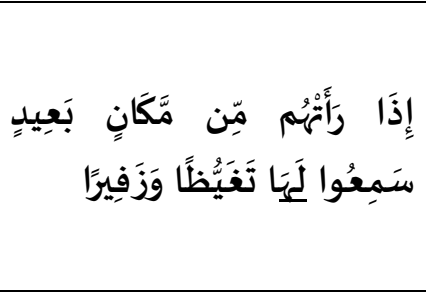 & 13 \\
\hline $\begin{array}{l}\text { llahum fìhā mā yasyā'ūna khälidīna.../ 'Bagi } \\
\text { mereka segala yang mereka kehendaki ada } \\
\text { di dalamnya (surga), mereka kekal (di } \\
\text { dalamnya)...'. (QS. Al-Furqān: 16) }\end{array}$ & 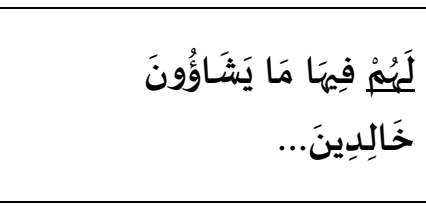 & 14 \\
\hline 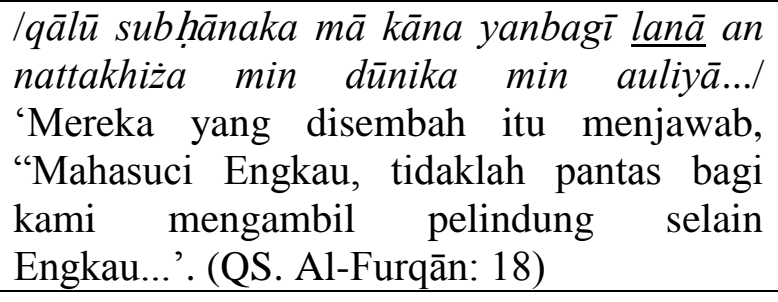 & 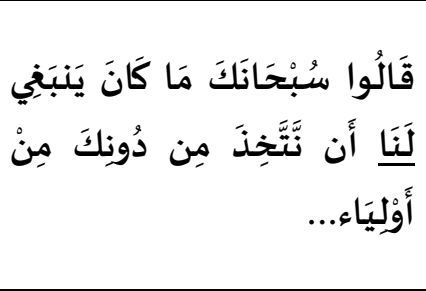 & 15 \\
\hline
\end{tabular}




\begin{tabular}{|c|c|c|}
\hline $\begin{array}{l}\text { l...wa kāna assyaiţānu } \underline{\text { lilinsāni }} \\
\text { khażülal...Dan setan memang pengkhianat } \\
\text { manusia'. (QS. Al-Furqān: 29) }\end{array}$ & 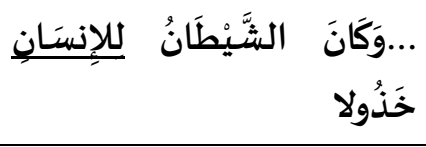 & 16 \\
\hline $\begin{array}{l}\text { Iwakażālika ja'alnā likulli nabiyyin } \\
\text { 'aduwwan mina al-mujrimina.../ } \\
\text { 'Begitulah, bagi setiap nabi, telah } \\
\text { kami adakan musuh dari orang-orang yang } \\
\text { berdosa...'. (QS. Al-Furqān: } 31 \text { ) }\end{array}$ & 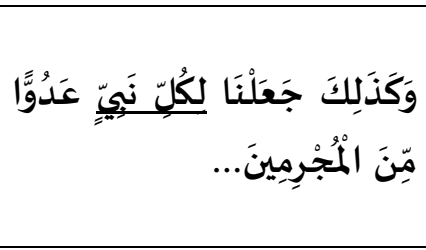 & 17 \\
\hline $\begin{array}{l}\text { /waqauma nūḥin lammā każżabū ar-rusula } \\
\text { agraqnāhum waja'alnāhum linnāsi } \\
\text { ayatan.../ 'Dan telah Kami binasakan kaum } \\
\text { Nuh ketika mereka mendustakan para rasul. } \\
\text { Kami tenggelamkan mereka dan Kami } \\
\text { jadikan (cerita) mereka itu pelajaran bagi } \\
\text { manusia...'. (QS. Al-Furqān: } 37 \text { ) }\end{array}$ & 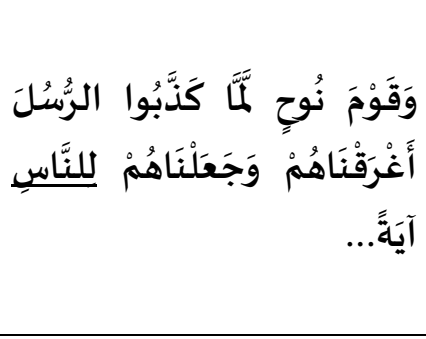 & 18 \\
\hline $\begin{array}{l}\text { Iwallażina yabìtūna lirabbihim sujjadan wa } \\
\text { qiyāman/ 'Dan orang-orang yang } \\
\text { menghabiskan waktu malam untuk } \\
\text { beribadah kepada Tuhan mereka dengan } \\
\text { bersujud dan berdiri'. (QS. Al-Furqān: } 64)\end{array}$ & 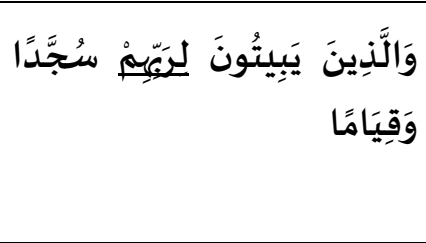 & 19 \\
\hline 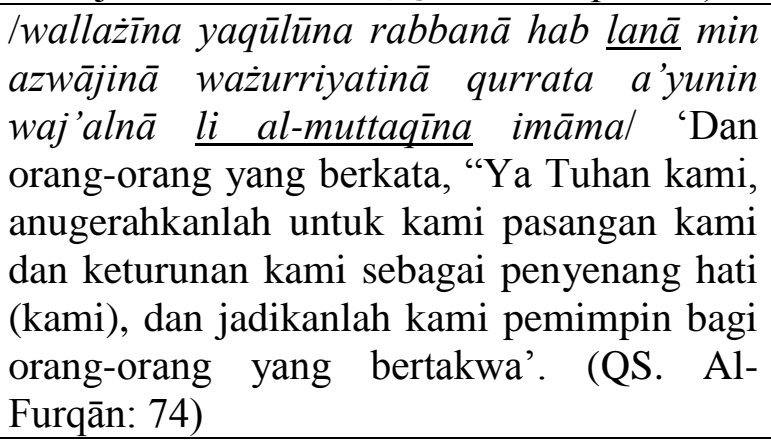 & 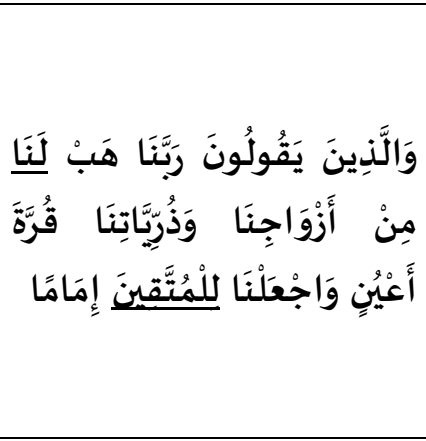 & 20 \\
\hline
\end{tabular}

Makna harf jar J/lam/ pada ayat ke-2 dan ke-26 dari surat Al-Furqān di atas adalah lal-milk/ yang artinya kepemilikian. Kata yang dimasuki 'lam' merupakan hal atau yang memiliki kata yang berhubungan dengannya. Syarif (1996) menyebutkan bahwa makna الملك /al-milkil dari harf jar lam adalah makna asli dari harf jar tersebut. Makna harf jar J/lam/ pada ayat ke-1, ayat ke-8 dan ke10 dari surat Al-Furqān di atas adalah شبه الملك/syibhu al-milk/ artinya adalah kepemilikan non hakiki (Syarif, 1996). Makna syibhul al-milk dari harf jar lam adalah makna dasar dari harf jar lam tersebut, karena makna tersebut merupakan jenis dari makna الملك /almilk/ yang merupakan makna dasar dari harf jar lam (Syarif, 1996). 
Makna harf jar J/lam/ pada ayat ke-11, ayat ke-15, ayat ke-22, ayat ke-37, ayat ke-60 dan ayat ke-69 dari surat Al-Furqan di atas adalah استحققاق /istihqāql, makna istihqqāq adalah menerangkan milik atau hak (Syarif, 1996). Ibn Hisyam (2010), membatasi bahwa harf jar lam bermakna istiḥqāq terletak pada makna dan dzat dari sebuah kalimat, dan juga terletak pada ayat yang berkaitan dengan balasan terhadap orang-orang yang kafir. Makna istiḥqāq adalah makna dasar dari harf jar lam tersebut, karena makna tersebut merupakan jenis dari makna syibhu al-milk yang merupakan makna dasar dari harf jar lam (Syarif, 1996).

Makna harf jar J/lam/ pada ayat ke-2, ayat ke-12, ayat ke-16, ayat ke-18, ayat ke-29, ayat ke-31, ayat ke-37, ayat ke-64 dan ayat ke-74 dari surat Al-Furqan di atas adalah إختصياص/ikhtişāş/ yaitu menunjukkan arti kepemilikan yang lebih khusus (Syarif, 1996).

\section{Penutup}

Di dalam Al-Qur'an surat Al-Furqān terdapat 59 makna leksikal, yang terdiri dari 8 jenis makna dari 8 jenis harf jar. Rinciannya adalah harf jar (preposisi) min makna leksikalnya adalah 'dari', yaitu menyatakan permulaan ( $\mathrm{al}$ ibtidā) berjumlah 5. Harf jar (preposisi) ilā makna leksikalnya adalah 'ke, kepada', yaitu menyatakan arah dan tujuan (intihā al-gāyati) berjumlah 9. Harf jar (preposisi) 'an makna leksikalnya adalah 'dari, jauh dari' yaitu melalui, melewati (al-mujāwazah) berjumlah 3. Harf jar (preposisi) alā makna leksikalnya adalah 'di atas' yaitu menyatakan tempat yang tinggi (isti'lā) berjumlah 6. Harf jar (preposisi) fi makna leksikalnya adalah 'di, dalam, di dalam' yaitu menandai keterangan tempat, waktu (Zarfiyyah) berjumlah 12. Harf jar (preposisi) ba makna leksikalnya adalah 'dengan' yaitu menyatakan alat (isti'ānah) berjumlah 2. Harf jar (preposisi) kaf makna leksikalnya adalah 'seperti, laksana' yaitu bermakna perumpamaan (at-tasybīh) berjumlah 1. Harf jar lam makna leksikalnya adalah 'milik, bagi' menyatakan kepemilikan (al-milk, syibhu al-milk, istiḥqāq dan ikhtișaș) berjumlah 21 . 


\section{Pustaka Acuan}

Al-Anşāri, Jamāludd̄̄n bin Hisyām. 1998. Awd'ah Al-Masālik Ilā Al-Fiyati Ibn Mālik. Riyādh: Dār Al-Mughn̄̄

Al-Ghulāyayn̄̄, M. 1994. Jami' Durūs Al-Arabiyah. Beirut: Maktabah AlAshriyah

Chaer, A. 2012. Linguistik Umum. Cetakan Ke-4. Jakarta: Penerbit Rineka Cipta

Darwīsy, M. 2011. I'rābu Al-Qurān Al-Karīm Wa Bayānuhu. Beirut: Dār Ibn Kaśīr

Departemen Pendidikan dan Kebudayaan. 1995. Kamus Besar Bahasa Indonesia. Cetakan Ke-4. Jakarta: Balai Pustaka

Departemen Agama RI. 2009. Al-Qur'an dan Terjemahnya. Depok: Penerbit SABIQ

Hasan, A. 2004. An-Nahwu Al-Wäfì. Avand Danesh LTD

Khuli, Muhammad Ali. 1982. A Dictionary Of Theorytical Linguistic (English Arabic). Lebanon: Librairie Du Liban

Miles, M.B, Huberman, A.M, dan Saldana, J. 2014. Qualitative Data Analysis. California: Sage Publications

Mukhtar, A. 1998. Ilmu Ad-Dilālah. Qāhirah: Ilmu Al-Kutub

Munawwir, A.W. 1997. Al-Munawwir Kamus Arab-Indonesia. Surabaya: Pustaka Progressif

Nazir, M. 2003. Metode Tulisan. Cetakan Ke-5. Jakarta: Ghalia Indonesia

Pateda, M. 2015. Linguistik Sebuah Pengantar. Edisi Revisi 2015. Bandung: Penerbit Angkasa Bandung

Surakhmad, W. 1989. Pengantar Tulisan Ilmiah: Dasar, Metode dan Teknik. Bandung: Tarsito

Syarif, Muhammad Hassan. 1996. Mu'jam Huruf Al-Ma'ān̄̄ Fi Al-Qur'ani AlKarim. Lebanon: Al-Resalah Publishing House

Verhaar, J. W. M. 1989. Pengantar Linguistik. Cetakan Ke-12. Yogyakarta: Gajah Mada Universty Press

Yunus, M. 1989. Kamus Arab Indonesia. Jakarta: PT.Mahmud Yunus Wa Dzurriyah 